\title{
Corporate Social Responsibility Practices and Stakeholders' Awareness
}

\author{
Dakito Alemu Kesto ${ }^{1 *}$, Jaladi Ravi ${ }^{2}$
}

${ }^{1}$ Research Scholar, Department of Commerce and Management Studies, Andhra University, Vizag, INDIA

${ }^{2}$ Professor, Department of Commerce and Management Studies, Andhra University, Vizag, INDIA

*Corresponding Contact:

Email: dalemu22@gmail.com

\begin{abstract}
The main aim of this review is to explore the corporate social responsibility practices and stakeholders' awareness about firms' CSR in Ethiopia. The concept of Corporate Social Responsibility (CSR) came into existence because of the impracticability of market economy and thus transfers some of the government and NGO's responsibility to private sector is required particularly in developing nations. Since the living standard of the society is low in emerging economies, the CSR expected from business firm is much higher than it is used to be in advanced economy. Ethiopia is one of the least developed countries and thus, the involvement of private sector is very crucial since government does not fulfill all needs of the society. In one way or another, businesses are economic entities that have the ability to change CSR activities into business opportunities. Several studies suggest that companies may receive external benefits from implementing CSR policies. However, the success of practicing CSRs depends upon the level of stakeholders' awareness. Specifically, in conducting the survey the reviewer was motivated by the following research questions which constitute the objectives of the article: (1) where do firms in Ethiopia categorized in the Carroll's 1991 pyramid; and (2) what was the level of awareness of different stakeholders in the country. Therefore, this review explores the CSR practices of firms and the level of stakeholders' awareness about the concept in Ethiopia. The paper employed qualitative research approach by reviewing 16 research articles which address CSR policies of firms in Ethiopia. The finding shows, the most important stakeholder considered by firms are customers which contribute to profitability. This shows the fact that firms in Ethiopia are in the lower-level of Carroll's CSR pyramid: economic responsibility. Furthermore, the level of stakeholders' awareness regarding the firms' CSR practice in Ethiopia is low. To summarize, corporate social responsibility practice in Ethiopia is at its infancy stage and thus, need much more improvement from both firms and the government.
\end{abstract}

Keywords: Stakeholders, awareness, review, corporate social responsibility, practices, Ethiopia 


\section{INTRODUCTION}

The concept of Corporate Social Responsibility (CSR) indicates the responsibilities that the business should take from the shoulders of the government and the NGOs particularly in developing nations. Since the living standard of the society is low in emerging economies, the CSR expected from business firm is much higher than it is used to be in developed economy. Ethiopia is one of the least developed countries and thus, the involvement of private sector is critical since government does not fulfill all needs of the society. In one way or another, businesses are economic entities that have the ability to change corporate social responsibility activities into business opportunities. According to Freidman (1970), "The conceptualization of CSR is based on two key questions: for what are corporations responsible? And to whom are they responsible? These questions have caused much philosophical and legal debate in order to address the issues. In other word, addressing such questions will lead to legal and philosophical arguments and make difficult to come up with a universally accepted definition of CSR. Therefore, for simplicity of understanding, definition given by Visser et al, (2007) is adopted in this study.

Globalization has led to an increase in private economic power of business firms rather than individuals. These corporations operate world-wide and it is generally recognized that their ultimate economic goal is many making, defined as the search for and maximization of profit (Karounga Diawara1 \& Sophie Lavallée, 2014). The role traditionally assigned to business managers is to promote the interest of member-investors, whether shareholders or partners (Friedman, 1962, 1970). As a result of the emerging concept of corporate social responsibility, the economic view of the corporate goal has been strongly reduced over the last few decades. Furthermore, the globalized thinking of business concepts has lead the business world towards a more advanced and well established system of transaction which business organizations are required to provide best quality with environmental friendly (ISO 9001 and ISO 14000) and socially responsible products and services. Even if the move for standardization of product and environmental qualities are noticed in the past few years, many things need to be improved by firms in Ethiopia otherwise ISO certificate does not guarantee the companies CSR practices for long.

Regardless of the idea difference in constructing universally accepted definition for what CSR is, the importance of different stakeholders' awareness about the firms CSR practices in building shared value and thereby make the CSR practices sustainable is immeasurable. Shared value refers to corporate policies and practices that enhance the competitive advantage and profitability of the company while promoting social and economic conditions. In order to do so, identifying the potential stakeholders and assessing their level of awareness about firms' CSR policies and practices are irreplaceable. As far as the knowledge of the reviewers are concerned, there is no organized study that summarizes the different stakeholders and their level of awareness with respect to firms' CSR practices in Ethiopia. Therefore, this review explores the corporate social responsibility practices of firms and the level of stakeholders' awareness about the concept in Ethiopia.

\section{METHODS}

Even if the traditional view of firm is maximization of owners' wealth, currently things have changed to broader view, corporate social responsibility (stakeholders' wealth maximization). Of course, the traditional view of business is a proper subset of Carroll's 1991 pyramid. Here are the basic questions: First, where do firms in Ethiopia is categorized in the Carroll's 1991 pyramid? Second, what is the level of awareness of different stakeholders in 
the country? Therefore, in order to address these questions, the paper employed qualitative research approach. The data used for this review was gathered from 16 research articles done during the period between 2008 and 2016 by different authors in Ethiopia. The reasons to focus only on papers conducted during these time periods are availability of the data and also the timeliness of the paper will help to draw inferences. The research articles reviewed address firms in Ethiopia particularly, manufacturing firms, floriculture industries, leather and footwear's, telecommunication, brewery factories, hospitality industry, soft-drink companies, oil distributing firms and financial institutions.

\section{DiscuSSIONS}

Several studies suggest that companies may receive external benefits from implementing CSR policies. Empirical studies have found that CSR is linked to more favorable corporate evaluations by growing purchase behavior (Lichtenstein et al, 2004), superior customer satisfaction and overall market value of a firm (Luo \& Bhattacharya, 2006) all of which is believed to translate into increased profitability for the corporation. Furthermore, in one way or another, the success of practicing CSRs depends upon the level of different stakeholders' awareness. Therefore, the following sub-sections discuss the awareness and perception of different stakeholders about the firms' engagement in CSR activities in Ethiopia.

\section{Stakeholders' Awareness and Perception of Firms' CSR Practices}

There is evidence that CSR is beneficial because, as with customers, CSR improves employees' perceptions of the company. This means, as the firms engage in CSR activities, the reaction of stakeholders such as customers and employees will be higher and thereby optimize both shareholders' and stakeholders' wealth. When a company has CSR initiatives, employees are more proud of and committed to the organization (Bramme et al., 2007). For instance, research conducted in Africa using Center for Creative Leadership's (CCL's) World Leadership Survey also supported this finding: employees' awareness of their organizations' commitment for the community and environmental concern is linked to their level of organizational commitment. That is, the higher an employee rates their organization's corporate citizenship, the more committed they are to the organization (Sarah Stawiski et al., 2011). This implies, the more the employees become committed, the higher the firms' efficiency in production of goods and services. The figure below presents the employees mean score on organizational commitment (which is given vertically) and employees' perception (which is given horizontally) using likert scale.

Figure 1: Relationship between Perceived Corporate Citizenship and Commitment

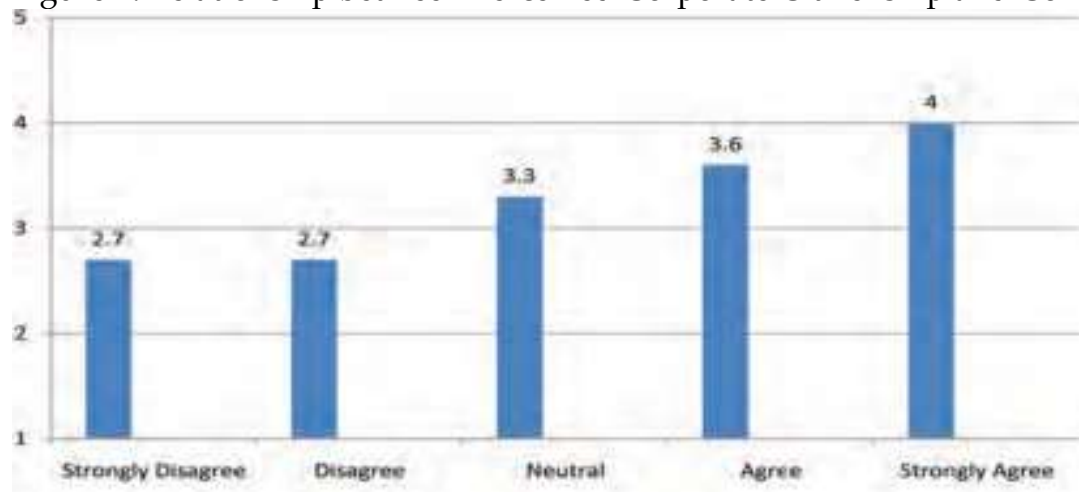

Source: Sarah Stawiski et al., (2011) 
From the figure above, one can infer the fact that, it is likely the case that the relationship works both ways; commitment enhances employees' ratings of corporate image and positive image increase employees' commitment. It makes sense that knowing (awareness) about the good deeds of an organization might make an employee more eager to discuss their company and increase their commitment to their organization accordingly. Similarly, either way, awareness of CSR is one of the many factors that affect employees' commitment and thereby companies efficiency. From this, firms should learn how important is discharging CSR given that properly handled and incorporated in the firms' strategic plan.

Mohana Rao and Fentaye Kassa (2016) examined the awareness of employees towards environmental corporate social responsibility initiatives of Brewery firms in Ethiopia. They employed a cross-sectional research design in order to gather data only at the time of the survey. Moreover, they employed convenience sampling technique in order to select participants and collected primary data from a total of 429 employees of five major brewery firms in Ethiopia: BGI Ethiopia, Meta Abo, Bedele, Harar and Dashen. Now days, firms are taking proactive actions to reduce carbon emission by incorporating in their policy with respect to environment. Large number of respondents (81.6\%) revealed their agreement on the concern of companies to show their responsibility on the disposal of wastes and residues, which involves recuperation and recycling systems. The finding revealed that employees hold positive perception of Environmental CSR initiatives of firms in brewery industry however, firms allotted a limited attention to create awareness about environmental management to the external stakeholders. This by-impliedly shows the fact that, brewery factors fails to advocate the CSR practices to other stakeholders which might substantiate their efforts to keep green environments on top of employees' commitment.

On the other hand, Ezana Messele (2014) assessed the stakeholders' awareness on CSR practice of Meta Abo Brewery S.C using both qualitative and quantitative research approaches and it is mainly dependent on primary source of data in which four types of structured questionnaire was developed to get data from 182 respondents composed of 60 customers, 52 community, and 60 employees while 10 managers of the companies were interviewed. The findings depicts that the employees awareness towards concept of CSR is at its lowest level. Similarly, majority (60\%) of the customers don't know anything about company's CSR practices. Furthermore, even if many of the community knew about the company's philanthropic contribution, still majority $(67 \%)$ of the communities were unaware of firm's environmental CSR practices. From this one can conclude that the company was not working with the community aspects particularly issues related to the environment concern. In other word, even if top-managements are aware of the CSR practices of the company, the majority of the employees, communities, and customers did not know the company's CSR policy. The stakeholders' awareness on components of CSR includes economic, ethical, legal, and philanthropic responsibilities are accepted as an important aspect to business organizations socially responsible activities. However, the prioritization of CSR to the company includes philanthropic. In general, stakeholders awareness about Ethiopian firms CSR practices are low which could hurt firms' willingness and also financial performance adversely.

According to Abeba (2014), a research made to identify business understanding of benefits of CPR, $20 \%$ of the respondents believe CSR will decrease profitability, and 30\% believe practicing CSR has no impact on profitability. The $50 \%$ of the respondents that don't 
believe CSR has any significant effect to financial performance. Furthermore, firms' understanding of different stakeholder is not balanced. When asked which stakeholder is most important to them, $50 \%$ of respondents responded it's their customers they value the most. $20 \%$ of the respondents said it's their employees, and the remaining $30 \%$ is equally allocated to suppliers, government and society respectively. It can be seen here that the most important stakeholder for business organizations in Ethiopia are customers and this implies there is several CSR practice that can be integrated with customers' awareness and thus optimize firms' profitability. This shows the fact that the main concern of firms in Ethiopia is just profit maximization, lower-level of Carroll's CSR pyramid. As presented in the figure 2 below, the Carroll's pyramid has four major categories of responsibilities: Economic responsibilities, legal, ethical, and discretionary (philanthropic) responsibilities. Profit maximization or economic responsibility is the foundation upon which all other responsibilities rest. Legal responsibility is mainly respecting law which the society codified about what is right and wrong. In other word, firms should play as per the rule of the game. Similarly, ethical responsibility is more or less laissez-faire types of law in which firms do what is right, just and fair by avoiding harms. On the other hand, discretionary responsibility (philanthropic) is more subjective and mainly based on the individual managers feeling and it seems the extension of individual social responsibilities.

Figure 2: Carroll's corporate social responsibility pyramid

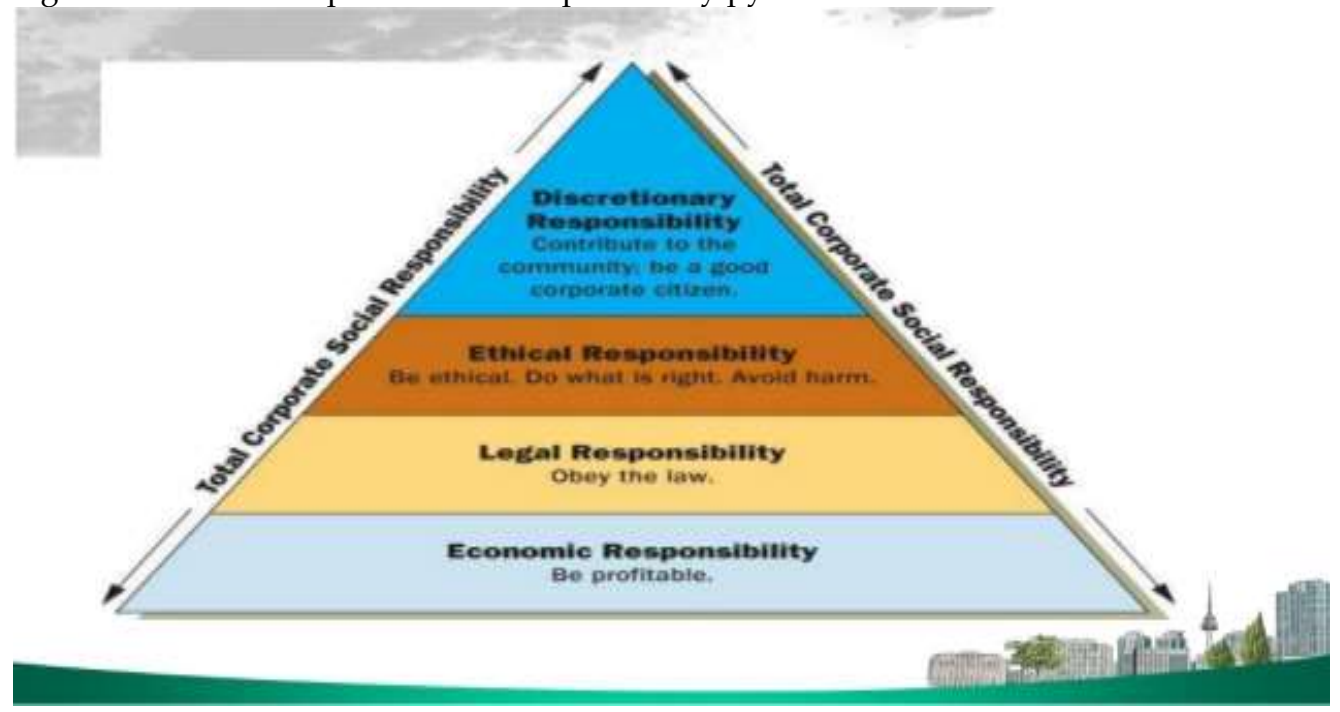

Source: Adopted from Carroll's 1991 CSR Pyramid

As discussed in the following sub-section clearly, regardless of the four categories of CSR, firms in Ethiopia mainly practicing the foundation, profit maximization and to some extent the discretionary responsibilities. To sum up, however, the level of different stakeholder awareness regarding the firms' CSR practice in Ethiopia is very low even if firms trying to discharge their responsibilities.

\section{Corporate Social Responsibility Practices of Firms' in Ethiopia}

As discussed above, brewery factories in Ethiopia were discharging corporate social responsibilities with respect to economic, philanthropic and environmental concerns. According to Workineh Bayisa and Daniel Tolesa (2015), examined the attitude of managers, employees and local communities towards CSR practices of manufacturing 
firms in Ethiopia particularly in Sabata and Gelan town near to the capital city where many manufacturing firms reside. They used the four major stakeholders (community, customers, employees and environment) as a measure of corporate social responsibility practices of the manufacturing companies and then link of the CSR to the profitability of the enterprises. They used structured questionnaire to collect data from managers, employees and local community. The results of their study found that the firm did not practiced discretionary role to help the surrounding community and specifically from the local community view point, social contribution of manufacturing firms is limited. Furthermore, manufacturing firms surveyed have not properly carried out CSR activities especially in waste management. On the other hand, public owned manufacturing firms are found to be more responsive to communities CSR activities than foreign owned (multinational companies) and private owned domestic firms in the study area. Similarly, larger firms are more responsive to CSR than smaller ones and socially responsible firms are found to be financially successful than others.

Socially Responsible Labor Practices (SRLPs) are part of a nation-wide employment and social protection strategy prepared by the Ethiopian government that calls for workers' rights. However, there is no significant focus to the development and implementation of employment and social protection strategy. For instance, Asnake Menbere (2016) examined the level of understanding and practical implementation of socially responsible labor practices in Ethiopia taking Metahara Sugar Factory as case study. The finding shows that the main social responsibility practiced was related to philanthropic activities. This implies the fact that the concept of social responsibility is not internalized so as to practice in a manner that could contribute for sustainable development. There are progressive individual company initiatives to implement socially responsible behaviors. However, they identified gaps that impede the realization of this issue. The major impediments include, society's attitudinal problem and mistrust towards these companies, weak communication and lack of collaborative endeavor among various stakeholder towards the implementation of the same.

According to Asemamaw Tilahun (2011), multinational corporations, local companies, and social enterprises use various environmental concerns in discharging their CSR for sustainable environmental management in the country. Using both primary and secondary data, the researcher has investigated the approach they use and the factors that force corporations and social enterprises to engage in environmental preservation. The finding shows that enterprises are discharging their responsibility to sustain environmental management through education, formal discussion, and by safeguard the environment. Corporations and social enterprises engage in environmental management to influence of legislators, customers, competitors, and also want to improve relations with the local community.

Unlike the developed countries in which the corporate governance system plays a key role in ensuring the ethical business practices, countries without vibrant stock market like Ethiopia face lack of well-established ethical business practice since active market pushes firms to adhere with different stakeholders. Firms in Ethiopian flower industry are at their early stage to generate a sufficient amount of hard currency and create job opportunity for several citizens. However it is still accused of unsustainable flower production. Study conducted by Samson Mechale and Messay Shibre (2011) explored the practice of corporate social responsibility and the related governance on Ethiopian flower industry. It highlights particularly on CSR and their respective practices through the assistance of 
government and different stakeholders. Beyond the firms' business conduct, the government is expected to ensure the sustainability of business practice of flower production. Accordingly, environmental issues like proper handling and usage of pesticides, fertilizers and other chemicals, waste disposals, water and soil conservations, community and employees' related health and safety and other issues are by Environmental Impact Assessment, Code of Practice and legislations.

Similarly, Tedla Zegeye (2013) explored the practice of corporate social responsibility of Ethiopian flower industry. The study attempts to explore the growth of the industry, corporate social responsibility practices and governmental commitment with its CSR drivers. In other word, the study assessed the CSR practice from the three pillars: economical, ecological and human practices of flower farms in Ethiopia with its related CSR drivers in promoting their governance on corporate social responsibility. He found that the Ethiopian horticultural industry has begun to realize the importance of involvement in CSR practices from economic, social and environmental issues. The firms in the industry attempt to exercise the CSR programs as a responsible business practice from their own business profit aspects that contribute to increase the economic aspects. There also an attempt for social issues which is highly related with employees benefits. Furthermore, the research shows that the most important stakeholders for the CSR initiatives are investors and followed by employees and customers, and Ethiopian Horticulture Producer Exporters Associations (EHPEA). The EHPEA voluntary code developed is also very important to practice CSR Programs. On the other hand, the demand for CSR practices is originally driven by marketplace expectation and comes mainly from overseas customers and this lead firms' to have CSR as its main motives for CSR were a morality the right thing to do and needs to keeping its company's reputation. From society's point of view, the industry has got a lot of challenges which are emanated from lack of positive image building activity that the product needs by its nature. However, different interest groups, e.g. owners or shareholders, employees according to respondents' government support for CSR practice is very minimal.

Mouly Potluri and Zelalem Temesgen (2008), analyzed CSR using structured questionnaires and in depth interviews with 50 Ethiopian companies, customers, creditors and suppliers, general public or community at large and government. Furthermore, to cross validate, the researchers also conducted a survey with another three questionnaires to obtain the views of 100 employees, 200 customers and another 200 general public. The finding shows that, Ethiopian companies expressed 100 percent positive attitude (theoretically) in implementing CSR towards customers, creditors and suppliers, general public and government. However, actually only 40 percent of firms were willing to disclose information to shareholders. Similarly, 80 percent firms believe that fair wages and security of employment are important. Contrary to this, 10 percent of firms had negative attitude towards employees' freedom, job satisfaction and humane treatment. This finding was substantiated by the cross question. Accordingly, overall 69 percent employees were not happy with firms' policies, 71 percent customers thought they were not properly treated by companies and another 75 percent general public were not satisfied with corporate social responsibility practices of firms in the country, Ethiopian. The finding shows, in one way or another, firms in Ethiopia were not properly handling the CSR. In a similar vein, Tewolde Mezgobo (2012) has illustrated corporate social Responsibility of sample firms in Ethiopia using Carroll's model. He argued that, the legal and ethical responsibilities are the least in terms of practice as it is the case in most of African countries context. This finding by-impliedly shows the fact that most firms in 
Ethiopia used to practice mainly the economic responsibility and philanthropic responsibility. In either of the two responsibilities, the target of firms in Ethiopia is maximization of profit or shareholders wealth since firms in Ethiopia use philanthropic responsibility to maximize market share over the competitors.

Mathias Nigatu (2015), applying organizational learning concepts investigated CSR learning in the leather and footwear firms of Ethiopia using case study. Moreover, interviews and content analysis of regulatory documents were the main methods employed. The findings show that firms' learning social responsibility is at emergence stage with the state and foreign market pressure as key motivators. While regulating environmental and labor conditions, the state offers incentives for higher economic responsibility of firms. This may because of the economic policy of the country, market economy where the focus of business is all about maximizing shareholders' wealth.

In order to develop telecommunications, Ethiopia met with some world famous telecommunications companies. However, only ZTE accepted and entered the telecommunications market of Ethiopia in by established an Ethiopian branch in 2007. Since then ZTE has improved the overall level of communication technology in Ethiopia and also created job opportunities for citizens. Furthermore, during 2010 and 2012, ZTE Corporation trained 1,000 engineers for Ethiopia for free. Similarly, since 2010, ZTE has provided free-of-charge social training opportunities for over 12,000 people in Ethiopia. ZTE has been utilizing its technologies to upgrade the communication facilities in emerging countries and regions, so as to contribute to the eradication of the digital divide (ZTE CRS report, 2013).

Currently, hospitality industry establishments especially hotels and lodges are the major business area in Corporate Social Responsibility (CSR) concern in 21st century. Hailu and Nigatu (2015) investigated the tourism and hospitality industries employee oriented CSR practices in the first level hotels and lodges in Gondar city by applying descriptive type of research. Accordingly, 133 employees were included in the sample from ten hotels and lodge which have served more than a year. Moreover, for the interview, all the ten first level hotels and lodges managers were approached. Their finding shows that, the first level hotels and lodges in the Gondar city practice gender equality and balancing the private and professional life of employees by providing freedom to go freely in sick and maternity. However, firms in the industry were less practiced issues related to reward and proper salary system, secure job and promotion of employees.

According to Abeba (2014) East Africa Bottling Share Company (EABSC) is spending at least $1 \%$ of prior year's EBIT (Earnings before Income Tax). To make a significant impact they usually prefer to make sizeable contributions to specific number of high value projects rather than small ad hoc grants. Some of the companies CSR projects are: Provision of Water, Women Empowerment, Active Healthy Living (Coca-Cola Road Race), Local Community Development Programs, Environmental Protection, and Health Sector (periodical blood donation). Similarly, Total Share Company Ethiopia, consider and participate the following activities as responsible: Road \& Safety, Tackling Malaria \& HIV AIDS, Planting trees every year, sponsoring health related programs, and Access to Energy. One of their sustainability programs is to provide solar energy for the vast majority of Ethiopians who are in short of electricity power. This program includes providing two types of lamps that work with a solar energy that can be charged with sunlight and be ready for use that could directly or indirectly maximize their economic benefits. On the other hand, according to Yenenh Taddese (2015), the role of private banks 
in Ethiopia has lower awareness to support greener industries, less options is provided to provide loan to low income borrowers, less practiced in community development activities and poor understanding on financial management in banking sector which results to adverse effect to the environment and society. Similarly, according to Dakito Alemu (2016), banking firms in Ethiopia focus is mainly resembles to customers concern and less attention is given for other concerns.

\section{Challenges of practicing CSR in Ethiopia}

Corporate governance is one of the cornerstones for corporate social responsibility which helps to secure the economic responsibility of the firms as clearly stated in the Carroll's CSR pyramid. Ethiopia doesn't have well-developed stock exchange market and as a result there is no well-developed corporate governance system which is dependent on it. However, the commercial code of Ethiopia which was enacted in 1960's is not capable enough to address the current economic and changes in management philosophy, CSR. The Commercial Code of Ethiopia simply set the rules and regulations for internal governance of business activities where the article of association of a company is required for establishment. Even if a number of advocacies are ongoing, still CSR practices in Ethiopia are not backed by rules and regulation except with limited restriction on the environmental concerns as a result of push from the activist. On the other hand, the absence of awareness from the large group of society about CSR practices of firms in Ethiopia as a result of either lack of information or illiteracy has also considered as a challenge. Finally, firms in Ethiopia are practicing their CSRs just for brand building rather than considered as a responsibility.

\section{Conclusions}

According to Bernardo (2014), now a day's organizations are adapting to changes in the economy constantly, and those that adapt best have the greatest possibilities to survive in the market. A key factor for their success/survival is innovation, which is critical to sustain customer satisfaction and enhancing competitiveness in the long term. Furthermore, innovation is usually defined by including products and services, and management processes. From this one can infer that, CSR in itself is an innovation for companies' management in which firms should need to see out-of the box (profit maximization philosophy) to the holistic approach of optimizing different stakeholders' needs. The past few decades have shown an increase towards firm role in social and environmental activities rather than business as usual concept. Such corporate social responsibility role became a crucial philosophy for corporate success and sustainable development. In the process of practicing CSR so as to optimize societal needs, the counter parties' awareness is equally important to build CSR culture in the long-run. When a firm has corporate social responsibility initiatives, employees are more confident of and committed to the organization (Bramme et al., 2007). The brewery factories in Ethiopia were discharging both corporate social responsibilities with respect to economic, philanthropic and environmental concerns. Contrary to brewery factories, other manufacturing firms did not properly play discretionary role. Furthermore, manufacturing companies considered have not properly discharged their CSR activities especially in waste management. But, public owned manufacturing companies are found to be more responsive to societal CSR activities than multinational companies and private owned domestic companies in the study area. 
On the other hand, Metahara Sugar Factory participates in socially responsible practices but their activities were limited to philanthropic activities and thereby imply the fact that the concept of social responsibility is not fully implemented. Furthermore, Ethiopian horticultural industry has begun to realize the importance of involvement in CSR practices from economic, social and environmental issues. The firms in the industry attempt to exercise the CSR programs as a responsible business practice from their own business profit aspects that contribute to increase the economic aspects. There also an attempt for social issues which is highly related with employees benefits. In general, the findings show, in one way or another, firms in Ethiopia were sufficiently handling the CSR. The legal and ethical responsibilities are less in terms of practice as it is the case in most of firms in the country. This finding by-impliedly shows the fact that most firms in Ethiopia used to serve mainly the economic responsibility and philanthropic responsibility. The possible reason may be because of the fact that Ethiopian firms' learning social responsibility is only emerging and foreign market pressure is less. To summarize, corporate social responsibility practices in Ethiopia are at its infancy stage. Taking the finding of different researchers, one can conclude the fact that the CSR practices in the country is at the lower level of Carroll's CSR pyramid: profit maximization or economic responsibility. May be this is true as a result of:

- The current government policy overemphasizes on privatization and thus advocates firms to engage only on the money making activities;

- The commercial code of the country is old and silent about the issues about CRS practices;

- Absence of strong association of employees, consumers, environmental activist in the country; and

- $\quad$ Lack of well-developed capital market in Ethiopia.

\section{SUGgeStIONS TO OPTIMIZE THE CSR PRACTICES IN ETHIOPIA}

In one way or another, in general, the revised papers highlighted the fact that CSR fails mostly because it is not properly advocated and incorporated in the businesses overall objectives and strategies. Moreover, firms' understanding of different stakeholder is not balanced.

- Therefore, the researcher recommends to the business sector in Ethiopia that businesses should identify their stakeholders, and plan its CSR along with its business strategy in a way that it will promote the business and optimize the wealth of the society.

- Moreover, firms in Ethiopia should advocate their CSR policies and practices to different stakeholders so as to build shared value.

- Furthermore, to make multinational companies investments effective for the society, matching developmental programs (education, utilities, etc required by the local communities) to the MNC activities should be done by Ethiopian.

- One of the reasons for firms to discharge their CSR is the fact that they need to maximize shareholders wealth. Thus, to be effective and efficient, firms in Ethiopia should go beyond the economic responsibility.

- Government of Ethiopia should develop strong rules and regulation that push firms to adhere to the CSR activities properly. 


\section{REFERENCES}

Abeba Assemaw (2014). The Positive Impact of Strategic Corporate Social Responsibility to Profitability of Businesses in Ethiopia. Master of Business Administration thesis. Lincoln University. https://www.academia.edu

Asemamaw Tilahun (2011). Corporate Social Responsibility in Sustainable Environment Management in Ethiopia (The case of selected corporations and social enterprises). Addis Ababa University. etd.aau.edu.et/bitstream

Asnake Menbere (2016). Analyzing Social Responsibility towards Improving Labor Practice Issues in Ethiopia. MSc Thesis. Norwegian University of Science and Technology. https://brage.bibsys.no/xmlui/handle

Bernardo, M. (2014). Integration of management systems as an innovation: A proposal for a new model. Journal of Cleaner Production, 82, 132-142. http://dx.doi.org/10.1016/j.jclepro.2014.06.089

Bramme, S., Millington, A. \& Rayton, B. (2007). The contribution of corporate social responsibility to organizational commitment. Int. Journal of Human Resource Management, 18, 1701-1719.

Carroll, A.B. (1991). The pyramid of corporate social responsibility: toward the moral management of organizational stakeholders. Business Horizons, July-August, pp. 39-48.

Dakito Alemu (2016). Corporate Social Responsibility and Corporate Financial Performance Tradeoff. An empirical study in the case o banking sector in Ethiopia. Unpublished.

Ezana Messele, (2014). Stakeholders Perception of CSR on Meta Abo Brewery Share Company. repository.smuc.edu.et/bitstream/

Friedman, M. (1962). Capitalism and Freedom. University of Chicago Press.

Friedman, M. (1970). The Social Responsibility of Business is to Increase its Profits. New York Times.

Hailu FK, Nigatu TF (2015) Practices and Challenges of Corporate Social Responsibility (CSR) in the Hospitality Industry: The Case of First Level Hotels and Lodges in Gondar City, Ethiopia. J Tourism Hospit 4: 184. doi:10.4172/21670269.1000184

Karounga Diawara1 \& Sophie Lavallée, (2014). Corporate Social Responsibility (CSR) in the Ohada Law. Journal of Business Law and Ethics, Vol. 2(2), Published by American Research Institute for Policy Development. URL: http://dx.doi.org/10.15640/jble.v2n2a2

Lichtenstein, D.R., Drumright, M.E., \& Braig, B.M. (2004). The effect of corporate social responsibility on customer donations to corporate-supported nonprofits. Journal of Marketing, 68, 16-32.

Luo, X., \& Bhattacharya, C.B. (2006). Corporate social responsibility, customer satisfaction and market value. Journal of Marketing, 70, 1-18.

Mathias Nigatu (2015). Corporate Social Responsibility Learning in the Ethiopian Leather and Footwear Industry. https:/ / thesis.eur.nl/pub/32931/

Mohana Rao and Fentaye Kassa (2016). Environmental corporate social responsibility of brewery firms in Ethiopia International Journal of Applied Research 2016; 2(4): 01-07. www.allresearchjournal.com

Mouly Potluri and Zelalem Temesgen (2008) "Corporate social responsibility: an attitude of Ethiopian corporates", Social Responsibility Journal, Vol. 4 Iss: 4, pp.456 - 463. http:/ / dx.doi.org/10.1108/17471110810909867

Samson Mechale and Messay Shiibre (2011). "How is CSR practiced in the Ethiopian Floriculture Industry, and does it has a linkage with the governance system. www.divaportal.org/smash/get/

Sarah Stawiski et al., (2011). Employee Perceptions of Corporate Social Responsibility. The Implications for Your Organization. Center for Creative Leadership. www.cci.org 
Tedla Zegeye (2013). Corporate Social Responsibility Programmes in Ethiopian Floriculture Industry. MBA thesis. St. Mary's University College. repository.smuc.edu.et/bitstream

Tewolde Mezgobo (2012). The Nature of Corporate Social Responsibility (CSR) in Ethiopian Business Context. An Essay on Corporate Social Responsibility. PhD candidate at International School of Management. Paris. https://www.scribd.com/document/

Visser et al, (2007). Corporate Social Responsibility in Developing Countries. csr in global context. http://www.waynevisser.com

Workineh Bayisa and Daniel Tolesa (2015). Corporate Social Responsibility Practices and Financial Performance of Manufacturing Firms: A Case Study of Sebeta and Gelan Towns Zenith, International Journal of Multidisciplinary Research ISSN 2231-5780 Vol.5 (6), JUNE (2015), pp. 248-263. zenithresearch.org.in

Yeneneh Taddese. 2015. The Role of Private Commercial Banks on Corporate Social Responsibility in Ethiopia (Unpublished master's thesis) Addis Ababa University. etd.aau.edu.et/handle

ZTE CRS report, 2013. Corporate Social Responsibility Report. Sixth edition of the Corporate Social Responsibility Report released by ZTE Corporation. www.zte.com.cn

$$
--0--
$$

Publish Online and Print Version Both

ISSN Online: 2312-203X 